\title{
Abordaje arteterapéutico de un caso de inhibición creativa
}

\author{
Luis FORMAIANO $^{1}$ \\ luisformaiano@gmail.com
}

Enviado: 03/03/2011

Aceptado: 12/10/2011

\begin{abstract}
RESUMEN
Este trabajo presenta un caso clínico que describe el tratamiento arte terapéutico de un joven de 35 años de edad, artista y docente de plástica, que consulta porque su creatividad se encuentra inhibida. El tratamiento, individual, se extendió durante casi dos años, con la frecuencia de un día por semana. La exploración de diversos materiales y soportes, acompañada de consignas facilitadoras logró que emergieran deseos largo tiempo ocultos en su inconciente. Esto produjo la aceptación de contenidos escindidos que contribuyeron no solo al desbloqueo creativo sino también a una nueva forma de relacionarse con la vida.
\end{abstract}

Palabras clave: Arteterapia, inhibición, creatividad, pulsiones, autoestima.

\section{Referencia normalizada}

FORMAINO, L. (2011). “Abordaje arteterapéutico de un caso de inhibición creativa”. En Arteterapia: Papeles de arteterapia y educación artística para la inclusión social Vol.: 6. Páginas 105-118. Madrid. Servicios de publicaciones UCM.

\section{SUMARIO}

Introducción. Buscando una estrategia de trabajo. Desatando las manos. Rompiendo el molde. Exploraciones en el espacio, hacia la movilidad. Dando a luz. Conclusiones. Referencias bibliográficas.

\section{Art Therapy: a Case of Inhibition of Creativity}

\begin{abstract}
This paper reviews the case of a 35-year-old patient, an artist and teacher of art who felt that his creativity had been inhibited. The treatment, on a weekly one-to-one basis, ran for almost two years. The exploration of a wide variety of materials and supports, together with specific assignments, brought to his conscience desires that had been dormant for a long time. This resulted in the conscious incorporation of denied contents which not only contributed to the unblocking of creativity but also offered him a new way of relating to life.
\end{abstract}

Keywords: Art Therapy, inhibition, creativity, instincts, self esteem.

\section{CONTENTS}

Introduction. Searching for an adequate strategy of approach. Untying the hands. Breaking patterns. Exploring space, towards movement. Giving birth. Conclusions. Bibliography

${ }^{1}$ Licenciado en Psicología (Universidad de Buenos Aires). Arteterapeuta (IUNA). Socio Fundador Asociación Argentina de Arteterapia 


\section{INTRODUCCIÓN}

Mario, de 35 años, llega a consulta diciendo "yo pintaba, pero una vez una profesora hizo comparaciones entre mi trabajo y el de otros compañeros y sonó como mi mamá, descalificadora, dejé una materia por dos años, hacía intentos de volver a pintar pero aparecía la imposibilidad de llegar a la tela, siento que era poco lo que hacía para ponerlo ahí". Este es un punto clave en la historia artística personal de muchos sujetos, y se da con más frecuencia de la que suponemos. En referencia a estos sucesos marcadores, Cathy Malchiodi dice "A veces la gente recuerda a una persona en particular quien ridiculizó su producto artístico... o le otorgó una baja calificación". (Malchiodi, 1998:50). Pero como se verá mas adelante, y como lo explicita Donald Winnicott, lo creativo no solo está relacionado con lo artístico: "la creatividad... una coloración de toda la actitud hacia la realidad exterior." (Winnicott, 1971:93). Desde otra perspectiva, y citando al Dr Héctor Fiorini en su obra "El Psiquismo Creador", podemos pensar que las resonancias de este incidente contribuyeron a que el acto de crear - que "lleva consigo un estado de vértigo, de abismo, de libertad" (Fiorini, 2006:27) - cayese en lo imposible, con la concomitante aparición de un estado de angustia, facilitadora de bloqueos e inhibiciones. Freud definió la inhibición como "la limitación normal de una función, que puede ser considerada como síntoma cuando existe una desacostumbrada variación de ella". (Freud, 1925: 83). Ahora bien, en esta misma obra, "Inhibición, Síntoma y Angustia", Freud plantea que una inhibición puede tratar de evitar un conflicto con el Ello, cuando la función que resulta inhibida está teñida de erogenidad, o tratar de evitar un conflicto con el Super yo, que le niega al yo la posibilidad de alcanzar éxitos en lo que emprende, por no considerarlo merecedor de tales sucesos. La comparación que el paciente hizo entre su maestra, su madre y la descalificación - explicitada o no, por parte de ambas - llevaría a pensar que la inhibición se origina en el Super yo. Solo accediendo con mayor profundidad a otros aspectos de la historia de vida del paciente, que fueron emergiendo a medida que avanzábamos en le tratamiento, contribuirían a hipotetizar un origen relacionado con el Ello, donde es la convergencia entre la propia sexualidad (en términos de objeto/sujeto sujetado) como lugar de captura y el lugar de lo imposible (tal como es descrito en la tópica del psiquismo creador), lo que obstaculiza la posibilidad de crear.

\section{BUSCANDO UNA ESTRATEGIA DE TRABAJO}

El tratamiento tuvo lugar en mi consultorio / taller privado, a razón de una sesión semanal de 70 a 90 minutos de duración. La estructura de la sesión comprendía diez minutos de apertura, con lo que había ocurrido en la semana, le seguían cincuenta minutos de actividad plástica y entre diez y veinte minutos de cierre, donde se habilitaba la palabra con las resonancias y asociaciones producidas por el trabajo. En el primer encuentro con un nuevo paciente de arte terapia, siempre propongo como consigna un garabato porque considero que es una manera de indagar cómo éste se organiza en el espacio de la hoja, que cosas ve y rescata, como acomoda su percep- 
ción, lo que de alguna manera da cuenta de algunas de las imágenes que habitan su inconciente en ese momento particular. Por otra parte, el "garabatear está conectado con la historia personal artística de cada uno." (Malchiodi, 1998:106), y esto lo convierte, por lo tanto, en una excelente introducción al mundo de la generación espontánea de imágenes del paciente. De su primer garabato solo dice que le parece caótico, que le da la sensación de movimiento, de inquietud, de búsqueda, sin identificar ninguna figura en particular. ¿Es este el caos que abre la puerta hacia lo posible?

Un punto clave a considerar ha sido lo que Cathy Malchiodi define como "Ausencia de temor o de consideración sobre lo que los otros podrían pensar" (Malchiodi, 1998:73), ya que "la creatividad florece cuando interiormente sabemos lo que nos hace bien, y no, cuando nos basamos en los elogios o los juicios de los otros" (Op cit, p.74)

Por eso, en nuestro segundo encuentro le propongo explorar el poder de la palabra, utilizando como disparador un cuento llamado "Como plumas al viento", (Shua, 2003:315) al terminar el trabajo y refiriéndose a la palabra, dice: "no hay término medio o es motivadora o es cercenadora. Me dibujé entre el cielo y la tierra, mis dibujos de desnudos siempre fueron cuestionados y eso me suena a "cállate" o "no lo hagas". Aunque hay una llama interna que me rescata". Todo el tiempo él se cuestiona la timidez de la línea, diciendo que: "es demasiado suave". Cuando le pregunto que asocia con suavidad dice que la suavidad tiene que ver con lo femenino y le molesta reconocer que pueda haber algo de femenino en él.

A la tercera sesión trae el tema de la parálisis. Dice: "De chico mi vieja nos descalificaba a todos, ella era la suprema, me resuena la palabra INUTIL, me siento trabado para desatarme de esa creencia, siento las piernas atadas, quiero caminar y no me lo permiten." Tomando el emergente, le propongo trabajar la consigna “CCómo desato mis piernas?” Del dibujo final dice: "tiene inestabilidad, le falta equilibrio, siento el torrente de la vida por dentro, es difícil decodificar que pasa conmigo con lo que tiene que ver con los sentidos."

A mi pregunta sobre lo afectivo responde: "lo afectivo es como una telenovela, dejo pasar lo que siento porque pienso que tal vez al otro no le importe, siento impotencia ante la no manifestación de mis emociones, siento temor ante las caricias, cuando quise ser afectuoso me frenaron, me enferma frenarme y digo "que triste" y de a poco me apago." En este punto se evidencia una pérdida de lo vital, de la conexión con el Eros, y no solo respecto a la creación artística, sino también al vivir creativamente. Al respecto, Winnicott escribió:

Lo que hace que el individuo sienta que la vida vale la pena de vivirse es, más que ninguna otra cosa, la apercepción creadora. Frente a esto existe una relación con la realidad exterior que es relación de acatamiento; se reconoce el mundo y sus detalles pero solo como algo en que es preciso encajar o que exige adaptación. El acatamiento implica un sentimiento de inutilidad en el individuo, y se vincula con la idea de que nada importa y que la vida no es digna de ser vivida. (Winnicott, 1971:93) 
Entonces sugiero una consigna que ya había propuesto a otros pacientes y que había dado muy buenos resultados: "Desarticulando la palabra traumática". Esta consiste en elegir la palabra negativa más acuciante para el sujeto, en el caso de Mario fue "INUTIL". Se trata de escribirla tres veces, verticalmente, en tres hojas, luego, horizontalmente, como un acróstico, escribir palabras que incluyan cada una de las letras de la palabra elegida, o sea, una palabra horizontal por letra. En este caso, como INUTIL tiene 6 letras, habrá 18 palabras por página y 54 palabras en total por las tres páginas.

Luego, con tijera, se recortan las palabras, una por una y en dos hojas se pegan, en una, las que tienen connotación positiva y en la otra, las negativas. Las neutras pueden ubicarse en el medio. Finalmente, en una última hoja, se escribe un texto utilizando sólo las positivas y las neutras. El propósito de este ejercicio es desarticular el significado del significante, abriéndolo a muchas otras palabras que, combinadas de determinada manera, producirán un texto del que emergerá un nuevo significado. El texto que Mario produjo fue:

¿Cómo reducir los gritos de 'inútil' que todavía me llegan como un eco que atraviesa y desvela? ¿Cómo aflojar tanta dureza que me tensa y me cansa? Sorpresivamente recibo los mensajes de mis sueños que dejan caer sus matices en esta realidad insolente, ellos me alimentan y alegran. Cuando estoy sediento, lloro un poco para que vuelva. Ahora me veo insuficiente para poder contar lo magnífico de las cosas pequeñas y de lo osado de lo gigantesco. Me debo esforzar más por atrapar la fuerza impulsora de la creación, encender los sentidos y entender su decantación en mí para poder cantar como un humano más el suceso de vivir en este mundo.

Aunque Mario utilizó la gran palabra negativa, marcó un fuerte contraste comenzar con los "gritos de inútil" para terminar con "poder cantar como un humano más."

Para el cuarto encuentro retomamos el tema de lo afectivo y le propongo la consigna: "Lo que tengo para dar", trabajo del cual dice "no encontré lo bueno en mí, tengo necesidad de depender del otro, hice las huellas de una moto y un balón grande". Entonces sugiero ampliar el trabajo y tomar, primero, la visión que se produce desde la moto, y dice "es el vértigo, la curiosidad, lo nuevo, los posibles cambios, hay construcciones sólidas a mi alrededor, esperanza y dinamismo". Respecto a la ampliación del tema del balón, dice: "es una dualidad, lo empuja hacia arriba, yo también lo llevo hacia arriba, el camino lo veo como colorido, las líneas representan color también... me cuesta generar cambios, veo la vida en posición de nado, pero me cuesta aprender a nadar, me cuesta aprender a vivir". El trabajo, fue realizado en lápiz y sin utilizar color. Aparecieron, sin embargo, dos pares de opuestos a tener en cuenta para futuros trabajos: la horizontalidad (moto, vida en posición de nado, movimiento, cuesta nadar, cuesta vivir) y la verticalidad (balón que empuja hacia arriba, balón empujado hacia abajo, piernas que sostienen el cuerpo pero que están atadas, inmovilidad). Pero también surgió la pregunta de cómo podía ser libre para crear si tiene necesidad de depender del otro. Esto demostró que, de hecho, se en- 
contraba atado no solo al discurso sino también al deseo del otro, había quedado aprisionado en mandatos, pero desentenderse de ellos implicaba aprender a caminar solo.

Para la consigna sobre el personaje más cercano - entendido como identificatorio- y el más lejano - entendido como la sombra, desde una mirada Junguiana; Mario hace, como más cercano, una oruga y dice: "es algo que detesto mucho, una oruga, es fea y se oculta, me siento feo y grotesco y trato de ocultarme". El azul, esparcido aquí y allá en el trabajo representa para él la incertidumbre - en otros trabajos volveremos al significado simbólico que Mario le otorga a este color. En cuanto al más lejano, dice "hice un pájaro, representa la libertad, no me siento lo suficientemente inteligente como para representarme como humano." En ambos trabajos hay un uso tímido del color aunque sobresale la fragilidad de la línea, que es ese trazo suave que tanto le molesta. Pero hasta el momento, en toda su producción y en las verbalizaciones posteriores se evidencia un discurso melancólico, un destino signado por la imposibilidad, por la aceptación de esa imposibilidad así como también una falta de consideración por sí mismo, por ejemplo al decir que no se siente lo suficientemente inteligente como para representarse con forma humana.. ¿Cómo crear si hasta vivir es un sinsentido? ¿Para qué o para quien crear? Como bien explicita Coll Espinosa "Crear tiene que ver con un trabajo psíquico, irrenunciable para la salud, y que nos permite tener la sensación de dos aspectos indiscutibles que conviven en el psiquismo: unidad y permeabilidad psíquica." (Coll Espinosa, 2006:153). Creo que Mario tiene que reunir sus "pedazos", algo que, como nos indica Sara Paín, "es del dominio del arteterapia." (Paín, 2008:50)

\section{DESATANDO LAS MANOS}

Ante el relato "El elefante encadenado" (Benavides, 2007:25), que utilizo como disparador, le propongo como consigna "La Libertad." En este trabajo ya introduce más color, y rápidamente me aclara que no son dos hombres a punto de tener relaciones sexuales lo que la imagen muestra - aclaración significativa que reconduce al terreno de lo imposible y la captura por la sexualidad - sino que se trata de tres etapas en su vida, a la izquierda, su infancia "no me dejaban ir a jugar", dice - en el centro "el largo adolecer", "sentía que me estaba volviendo loco, resignado a lo que me estaba pasando, quería reprimir mi sexualidad pero no podía," y concluye: "a la derecha es como me siento ahora, tratando de agarrar la rueda del dinamismo para empezar a movilizarme." Cómo no pensar ahora en los orígenes tempranos de esta inhibición creativa más allá del incidente con la docente de arte, en tanto Winnicott claramente expresa que "un rasgo importante del juego es que en él y quizá solo en él, el niño o el adulto están en libertad de ser creadores." (Winnicott, 1971:79). Jugar estaba vedado, así como también vivir su sexualidad con plenitud. Este último hecho abrió la vía para trabajar la relación entre la inhibición y su relación con Ello y la posible erogenización de la función. Pero también me hizo pensar en su relación con las emociones, ya que se representa, en este presente, como un hombremáquina (el cuerpo sería la estructura de la motocicleta). 
Durante marzo le propongo trabajar con texturas, estimulándolo con cajas que contienen diferentes elementos dentro, los que toca con los ojos cerrados y trata de asociar a alguna emoción o sensación y así surge una serie de trabajos donde va relacionándose con el color pero fundamentalmente con el material, especialmente la témpera, un material que lo ayuda a fluir.

Hacia fines de marzo le sugiero pintar con los dedos para lograr aún una mayor conexión con sus propias emociones y con el material, experimentando cómo este fluye sobre la hoja. Surgieron recuerdos tempranos "de chico, iba al río a juntar piedras, luego sentí algo así como las hierbas que ponía mi abuela para hacer el desayuno..." Al representar plásticamente esas sensaciones nace primero un caballo verde y de su proceso dice: "sentí los pelos mientras lo pintaba, y eso me produjo ternura". Del segundo trabajo, "El mar rojo", motivado por la exploración del color dijo: "la oscuridad de la noche me fascina y me da miedo, por eso incluí los azules más claros que me tranquilizaron, siempre hay algo detrás de la oscuridad, no es todo tan terrible. Me vino un placer inminente de sentir la libertad, de caminar descalzo, en vez de mar podría ser lana... tengo que seguir caminando, es esperanzador."

El trabajo con las texturas y el color dio nacimiento a una obra que considero clave, la consigna fue "Mi reino", el disparador un cuento llamado "Bertoldo conoce al rey" (Shua, 2003:122) y Mario dice:

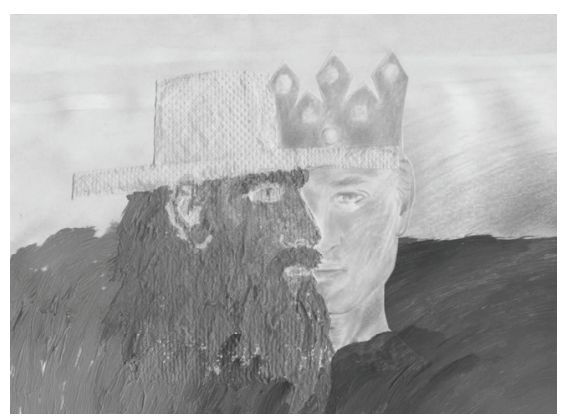

Fig. 1 "Mi reino"

En este trabajo, la línea y el color juegan un rol como nunca antes, ya que se suelta por completo y logra traspasar la barrera de la línea débil y del color tímido. El campesino con el que se identifica tiene su rostro color rojo fuego, pero luego, cuando dice "mi reino", pareciera estar refiriéndose a una revolución, donde el delicado rey que dibuja habrá de ser derrotado por esta otra parte suya, que no solo puede ser la lucha contra la imagen paterna sino también contra aspectos de su propio yo, el yo del trazo débil, el yo de la sexualidad cuestionada. Los materiales utilizados fueron témpera, pastel al óleo y papel de cocina.

El trabajo sobre Mi reino dio lugar a exploraciones sobre la valentía, sobre qué significa ser valiente, Mario trabaja sobre varias imágenes que representan su concepto de valentía: 
Ser valiente es desenrollarse y extenderse, como uno mismo mirando desde una ventana interna y empezando a salir, lo valiente es fugaz, no se queda conmigo, tiendo a escudarme para enfrentar situaciones, un valiente no usa escudos, ser valiente es pasar por ciertos lugares que parecen estables y no lo son tanto, me siento inestable en las nuevas estructuras, vulnerable cuando voy hacia delante...en realidad me considero cobarde, y lo relaciono con mi viejo, me siento inmerso en la desidia, éste (el de arteterapia) es el único espacio donde puedo ser yo.

Concluímos que toda creación implica una cuota de valentía. Y, paradójicamente, y volviendo a la frase del Dr Fiorini citada al inicio de este trabajo, el caos creador lleva consigo un estado de libertad y vértigo del que puede surgir una angustia que conduzca a una inhibición. De la misma manera que lo que había surgido en el trabajo sobre "Mi Reino", requiere mucha valentía llevar a cabo una revolución, más aún cuando esa revolución implica aspectos del propio yo y la figura paterna.

Para poder articular lo que habíamos venido trabajando en los primeros seis meses le propongo la consigna "Articulaciones". Los bocetos previos que hace en diferentes trabajos de fines de junio toman forman a principios de julio, al compartir conmigo su obra, Mario describe un brazo levantado sobre algo que asocia con un acantilado, el cuerpo está recostado. Le propongo dar vuelta el trabajo y para su asombro, el brazo se convierte en dos piernas firmemente plantadas sobre el suelo. Aquí juego con los conceptos que habían aparecido en uno de sus primeros trabajos, la horizontalidad y la verticalidad, la idea de piernas atadas y de manos que no pueden pintar, pero que están aprendiendo a sostener, así como también las piernas adquieren un rol de sostén. Sostén de sí mismo, de su cuerpo, subjetivación en construcción, "para que advenga sujeto desde su posición de objeto (donde es otro el que desea), trabajando con los objetos, recuperándolos y consagrándose como héroe." (Reisin, 2005:44)

Retomando su concepto de valentía y del hecho de desenrollarse, sugiero que trabajemos "Mis rollos", una consigna que consiste en tomar un rollo vacío de papel higiénico o de cocina, según la cantidad de rollos que se identifiquen y con cintas, tiras, lanas o cualquier otro material, identificar los rollos que uno cree o piensa que tiene para poder desenrollarlos y trabajarlos de a uno. Como precisamente aparece la inhibición del acto creativo como un rollo, le propongo hacer un trabajo auto observándose mientras crea. Al finalizarlo, y habiendo trabajado muy sueltamente con témpera, concluye en que había sentido: INSEGURIDAD (por el tamaño de la hoja, número 6), y eso le produjo temor de no poder manejar el espacio, PLACER (por la puesta del rojo, que recuerda que en "Mi Reino" representaba la cuota de audacia) TRISTEZA INFANTIL (ya que recuerda una imagen de niño, cuando estaba solo), ENOJO, (porque no podía dominar del todo el material, se le escapaba), DUDAS, (¿Por qué elegí este rollo y no otro?), lo que generó un AUTO REPROCHE, también sintió SORPRESA, (aparecen cosas que me agradan y que eran hasta desconocidas), ALEGRÍA, (puedo sentirme otro cuando pinto) y MO- 
VIMIENTO, (me moví para pintar). Agregó que había sentido la necesidad de poner más carga matérica.

En relación con otro rollo, que es su imagen física, primero propongo trabajar con "La mirada de los otros" y dice "no se defenderme, me retraigo y me ahogo de miedo, todo me salpica, a veces me represento como un náufrago en el océano, pero con la esperanza de tocar tierra otra vez." Dice que la base del trabajo que hizo es un gran salvavidas, el núcleo, un gran ensamblado de cartones.

Este tema del salvavidas y el náufrago será retomado más adelante.En cuanto a la visión de sí mismo, dice que solo rescata partes, "me cuesta mirarme a los ojos, o de cuerpo entero." La base del trabajo es altamente matérica y junto con el trabajo sobre la mirada de los otros - en el utilizó témperas y cartones - en este ha utilizado materiales que antes no había usado, como el papel glasé y el papel crepe. Pero ¿Qué decir de este cuerpo fragmentado, con esta auto imagen parcializada, desmembrada? Además, el cuerpo, que parece estar caminando hacia delante, está rodeado de trozos de papel azul, más oscuro en gran parte de los bordes con un toque de celeste detrás, que en un trabajo anterior había identificado como de efecto tranquilizador.

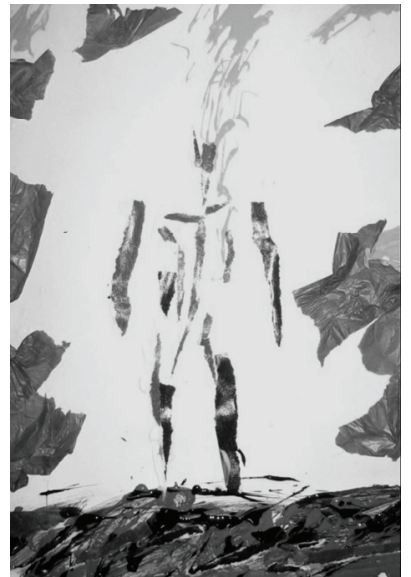

Fig. 2 "Como me veo"

\section{ROMPIENDO EL MOLDE}

La paulatina salida del espacio de la hoja y de la bidimensión se da con un trabajo cuya consigna fue "Rompiendo el techo", respondiendo a un emergente que el mismo trae cuando dice "necesito romper el techo, es como si tuviera un lastre en las piernas que no me deja crecer, necesito cambiar." Luego de finalizar el trabajo dijo que le gustó el desafío y que le dio seguridad. El elemento clave en este trabajo es el pasaje de una forma de representación a otra, pasaje que implica el paso de una tímida introducción del movimiento al movimiento en sí, ya que para armar una estructura tridimensional necesitó pararse, circular alrededor del trabajo, unir materiales y pensar estrategias que sostuviesen toda la estructura.

Todo septiembre retomamos el tema del miedo al azul, del salvavidas y del rescate, como una forma de recuperar (se).

En Octubre trabajamos la semilla, como símbolo de lo que está por nacer para generar un cambio.

En este trabajo, con un cuadriculado azul hecho con cartulina de colores, aparece representado un fragmento de su guardapolvo de la infancia. Cuenta: "es algo del jardín de infantes, quería demostrarle a los demás que yo podía coser, pero se me desprendió. Entonces, ahora deposito la semilla, para que germine, en el bolsillo de mi guardapolvo de jardín." Y así, coloca una semilla dentro de una esponja que 
recorta circularmente. Es interesante el juego entre semilla, germinar y jardín. Este trabajo solo cobrará su verdadera significación casi un año después.

El año se cierra con la consigna "Mis padres y yo". Mario relata que el padre mintió toda su vida y genera dudas en cada cosa que hace. Dice: "le faltó presencia espiritual, estuvo pero parecía no estar. De chico yo lo rechazaba, me daba asco que me tocara, ahora, con 70 años, me difama a mis espaldas, toda su vida se quejó de no haber sido amado, a pesar de haber tenido siempre amantes." Luego de un rato asocia su imposibilidad de producir con la falta de acción del padre y dice "me veo reflejado en su improductividad". Respecto a la madre dice que ella quería acercarse a él pero que se sentía desatendido y agrega "mi estado anímico era el de estar inundado de llanto y de bronca porque no me escuchaban, ellos me contaban sus problemas pero ninguno me atendía a mí". Es interesante como representa la figura del padre a su izquierda, mirando hacia él y extendiendo una enorme mano, y la figura de la madre, a su derecha, mirando para otro lado con ambos brazos abiertos que dan la sensación de un gran pico de ave. También es de notar el soporte sobre el que realizó el trabajo, cartón duro gris. El desafío continúa, Marián López Fernandez Cao nos recuerda que "nadie puede inventar nada... si no confía en su capacidad de juicio y decisión, y si tiene miedo a equivocarse. Ni siquiera puede inventar su propia vida, que permanecerá pegada a la de aquel o aquellos que cree que la legitiman." (Cao, Diez, 2006:21)

\section{EXPLORACIONES EN EL ESPACIO, HACIA LA MOVILIDAD}

El año siguiente comienza con una serie de bocetos para trabajos futuros en los que necesita despegarse del plano, me dice que solo va a poder entrar en movimiento si manipula en el espacio, si construye en el espacio, de alguna forma como lo había hecho ya con la consigna "Rompiendo el techo."

En preparación para dicho salto, le propongo la consigna "Abriendo la esquina del cuadro". Allí escribe: "amigos aventureros, brazos fuertes, risas contagiosas, espacios amplios y acogedores, caminatas reflexivas, piernas seguras, espíritu audaz".

La madeja y yo es un trabajo en tridimensión en el que explora los distintos problemas que lo acosan y su posición respecto a ellos. Se hace separado de la madeja y dice "quiero mantenerme en una plataforma para poder entrar y salir de la madeja sin quedar pegado".

Una figura móvil aparece en la consigna "Rompiendo la pared", símbolo que para él representa lo inhibitorio. Dice: "voy a poder hacerlo porque me siento bien parado, tengo mejor base que el paredón, cuento con mis brazos". Nos remitimos a aquel trabajo sobre "Articulaciones", que visto de una manera mostraba brazos sosteniendo a algo que había asociado con un acantilado y que, al cambiarlo de dirección, eran un par de piernas bien plantadas. Lo se que jugó bidimensionalmente ha cobrado cuerpo y ha ganado el espacio. La inhibición se materializó, cobró una identidad, es una pared a ser horadada. Como se verá en un trabajo posterior, se trata de romper algo para poder ser, para poder acceder, para constituirse como un sujeto libre, en ese "héroe" que menciona Alejandro Reisin en su obra. 
Luego agrega que le cuesta aceptarse como sensible, la pregunta que se hace es como lograr la contundencia desde lo suave. Le pregunto qué es ser suave, y dice que ser suave es ser femenino. Eso le molesta. Le hablo del "anima" y del "animus", de la parte masculina y la femenina, de la convivencia en cada uno de nosotros de estos aspectos supuestamente contradictorios, y que sin embargo, son complementarios. Otra forma de pensar la contundencia y la suavidad.

La siguiente sesión trabajamos la consigna "Mi estima", y ese día Mario sentenció: "a veces creo que si abro el cuerpo para poder ser, no va a salir nada, porque no hay nada." Dejé que la frase decantase en una producción y bajé a preparar café. Cuando volví al estudio, lo encontré tirado en el piso, había desplegado dos cartulinas y estaba pintando frenéticamente, con pinceles primero y con las manos después. Cuando termina dice: "siento que es contradictorio, como yo, oscuro y claro, me veo tan cargado de materia y etéreo a la vez que me preocupa." Aún así, marco la diferencia entre éste trabajo y la representación anterior de sí mismo que hizo en "Como me veo", nueve meses antes, aquí, el cuerpo ha cobrado consistencia, transmite mayor corporeidad y explora y acepta sus propios aspectos contradictorios. Aquí conviven lo contundente y lo suave. No

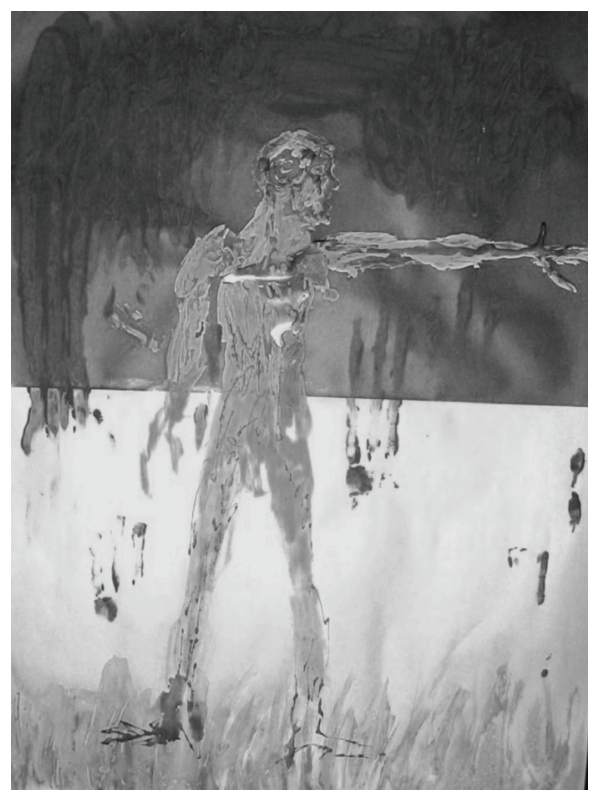

Fig. 3 "Mi estima" creo que sea casual que la cartulina de la parte superior sea de color azul. Los toques de rojo, el color de la audacia, también están ubicados en el parte superior del trabajo, dentro del cuerpo. La mano toca el borde de la cartulina, como lista para salir de ella. Abrir el cuerpo será abrir el espacio y desplegarse.

\section{DANDO A LUZ}

La sesión siguiente trae un jarrón o urna de arcilla que hace en su casa a partir de un sueño que tuvo en el que había una mujer dentro de un ataúd cerrado, amordazada y maniatada, que gritaba que le abrieran porque estaba por nacer su bebé. Creo que este sueño es decisivo en su recorrido, ya que alude a salir del encierro para poder ser, así como la sesión anterior se había referido a "abrir el cuerpo para poder ser," ¿ser que o ser como quién o ser para quien? Observando en detalle el jarrón o urna, se advierte que ha sido trabajado con pliegues, en cuya parte superior ha adherido 
tres pequeñas cabecitas, perfectamente talladas. Vida y muerte aparecen sugeridas por este trabajo, a la imagen de una urna ancestral, casi totémica, se le superpone la idea de algo continente, el jarrón útero. Algo comienza a moverse, algo muy profundo, su inconciente ha enviado un mensaje que el ha decidido no ignorar y lo plasma. Se inicia así una cadena de trabajos que dan cuenta del "sujeto de la construcción."

Esto origina un trabajo libre en sesión que hace en anverso y reverso, lo titula Gestación, y horada el cartón de manera tal de mostrar que algo fue parido.

La sesión siguiente trae un bebé de arcilla, dice "es un bebé que comenzó a querer gatear y se encontró con un manantial de vida". Considero a este trabajo como determinante ya que citando a Noemí Martínez Diez, "la arcilla es moldeable, suave, sensual y hace jugar, promueve la manifestación activa de uno de los procesos internos más primarios." (Diez; Cao, 2006:135). Dijo que su creación fue una experiencia liberadora, espontánea.

Sin embargo, esa misma noche me llamó por teléfono para decirme que quería desmantelarlo, que la idea era hacer un bebé mas grande, cuando le pregunté porqué me dijo que lo sintió como uno de esos objetos que se le ponían a los muertos precolombinos o egipcios en las vasijas funerarias. Le propongo que le de una oportunidad al bebé, por lo que decide ponerlo en una incubadora - o sea guardarlo envuelto en una

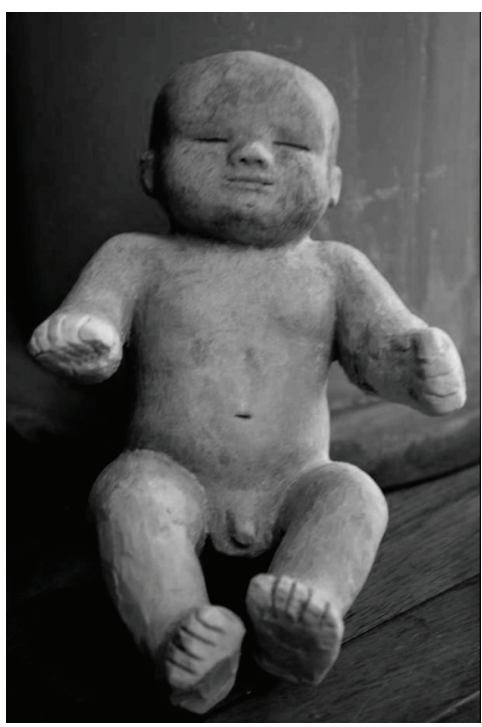

Fig. 4 "Bebé" heladerita portátil.

Nuevamente aquí aparecen enlazadas la pulsión de vida con la pulsión de muerte, como si el acto creativo conllevase la idea de generación/destrucción, de viraje de la movilidad a la inmovilidad, a la falta de tensión, al reposo absoluto. Esto explica cierta astenia que identifico con Mario. Pero lo más significativo, es que el bebé fue creado 9 meses después del trabajo de la semilla, que Mario había hecho en Octubre del año anterior.

El cuento "La montaña dorada" da pie para trabajar la consigna "Como alcanzar mi sueño" y entonces, con témpera y tiza realiza "construir mi horno de barro" y dice "es un pan que quise tuviera un horno donde siguiera cocinándose y cambiando y al salir, que siguiera desplegando los aromas y la forma". Nuevamente la vida, la gestación, el vientre-horno, como antes el útero-urna, vuelve la conexión con el Eros, con la tierra como elemento primario y con todo el simbolismo que la figura del pan acarrea. Y de este horno surge un "auto regalo", que representa con cinta para envolver y del que dice: 
"me gustó quererme sentir otra vez como activado, por eso los puntos luminosos en el cerebro, que estaba adormecido.... Y la sensación de tocar el cielo con las manos... sentí plenitud en el hacer... me gusta sentir la pintura como escultura, quitarme el prejuicio de que la pintura es algo plano...."

También menciona haber tomado distancia de su padre, dice que se cansó de su desprecio y de su ambivalencia, ambas características que en realidad le son propias pero no están del todo asumidas. Finalmente en Julio empieza a jugar con la idea de "hombres con pollera", algo que primero le parece descabellado y hasta le da miedo, pero que lo estimulo a explorar. Un bellísimo boceto - en el que la pollera está hecha con finos hilos de lana, lo que le otorga la sensación de delicadas plumas - da como resultado una obra en tridimensión absolutamente atrevida, en el que una pollera de arcilla roja que parece muy sólida y contundente y que llega al piso, en su parte superior se convierte en el níveo cuerpo de un hombre muy musculoso y masculino, con los brazos en alto, como si en cualquier momento fuese a liberarse de la pollera para poder volar.

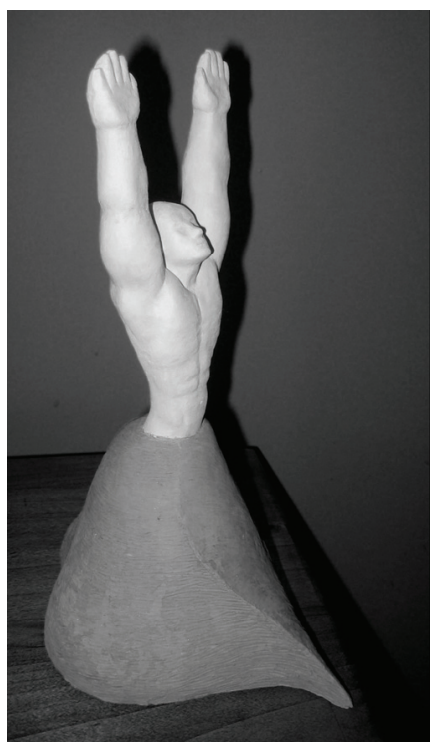

Fig. 5 "Hombre con pollera"

\section{CONCLUSIÓN}

El intenso recorrido fue un renacimiento, la primaria figura del hombre desmembrado se resignificó y solo cuando se volvió corpórea, estuvo en condiciones de horadar el material, abriendo su propio cuerpo a la creatividad inhibida, para volver a nacer.

Creo que el trazo suave que asociaba con lo femenino y que aparecía en sus representaciones bidimensionales, fue fortaleciéndose, primero, con intervenciones cargadas de materia hasta salir de la hoja para constituirse en el espacio gracias a sus producciones tridimensionales que, no en vano, comienzan con un bebé y finalizan con los hombres con pollera, pasando del cartón a la arcilla. O sea, esa contundencia desde lo suave que había mencionado meses antes se corporiza en un cuerpo que en su parte superior es fuerte, masculino, musculoso, pero de la cintura para abajo se refiere a lo netamente femenino, la pollera amplia oculta, pero también devela, el deseo de gestar, en ese horno de barro que se convierte en un útero que alberga la creación, un bebé de arcilla, logrando así la síntesis o el equilibrio entre su parte masculina y su parte femenina. 
Contratransferencialmente y en tanto yo también soy artista plástico, su inhibición creativa resonó en mí llevándome a esos momentos en los que mi propia pulsión creadora se pierde por intrincados caminos de incertidumbre y todo lo que pongo en juego cada vez que lucho por no ser capturado por lo imposible.

$\mathrm{Su}$ último trabajo es una esfera que se abre y permite leer cuatro palabras con las que cerramos el ciclo: SUEÑOS, AMOR, REALIZACIÓN y SALUD. Sara Paín dice:

El sentido de la terapia a través del arte es devolverle al cuerpo el derecho a emocionarse y a sentir el mundo, de llegar ser sujeto de la pasión. Porque las necesidades psíquicas son siempre las mismas, solo que, con sus prohibiciones y mandatos, cada momento de la historia abre ciertas posibilidades y cierra otras, provocando, así, las distintas descompensaciones que constituyen los síntomas de cada época. (Paín, 2008:53) 


\section{REFERENCIAS BIBLIOGRÁFICAS}

COLL ESPINOSA, F. J. (Editor) (2006): "Proceso creativo y simbolización en la clínica del arteterapia." En Arteterapia, dinámicas entre creación y procesos terapéuticos, Murcia, Editorial Universidad de Murcia.

FIORINI, H. (2006): El psiquismo creador, Teoría y Clínica de procesos terciarios, Buenos Aires, Editorial Nueva Visión.

FREUD, S. (1925): Inhibición, síntoma y angustia, Vol XX, Buenos Aires, Amorrortu Editores.

LÓPEZ FERNANDEZ CAO, M. Y MARTINEZ DIEZ, N. (2006): Arteterapia, Conocimiento interior a través de la expresión artística, Madrid, Ediciones Tutor.

MALCHIODI, C. A. (1998): The Art Therapy Sourcebook, Los Angeles, Lowell House.

PAIN, S. (2008): En sentido figurado, fundamentos teóricos de la arteterapia, Buenos Aires, Editorial Paidós.

REISIN, A. (2005): Arteterapia, Semánticas y Morfologías, Buenos Aires, Ediciones Centro Cultural del Borda.

SHUA, A. (2003): El libro del ingenio y la sabiduría, Buenos Aires, Alfaguara.

WINNICOTT, D. W. (1971): Realidad y Juego, Buenos Aires, Gedisa Editorial. 